\title{
CONTENTS OF VOLUME 45
}

RAVI P. AGARWAL and DONAL O'REGAN: Singular problems modelling phenomena in the theory of pseudoplastic fluids

YOUNG JOON AHN: Degree reduction of Bézier curves using constrained Chebyshev polynomials of the second kind

H. AL-AWADI: See P. J. HARRIS

M. AL-REFAI and K. K. TAM: Sequential eigenfunction expansion for a problem in combustion theory

SELMA BELEN and C. E. M. PEARCE: Rumours with general initial conditions

D. P. BULTE, L. K. FORBES and S. CROZIER: Phase-retardation effects at radio frequencies in flat-plate conductors

D. BYATT, I. D. COOPE and C. J. PRICE: Performance of various BFGS implementations with limited precision second-order information

PEEYUSH CHANDRA: See P. MUTHU

T. CARABALLO, J. A. LANGA and J. VALERO: The dimension of attractors of nonautonomous partial differential equations

K. S. CHAUDHURI: See T. K. KAR

YEOL JE CHO: See YAN SUN

H. J. CONNELL: See I. PENESIS

I. D. COOPE: See D. BYATT

G. M. COX and J. M. HILL: The limiting ideal theory for shear-index cohesionless granular materials

S. CROZIER: See D. P. BULTE

C. C. DALY: See A. B. PLEASANTS

ELIAS DEEBA, GHASSAN DIBEH, SUHEIL KHURI and SHISHEN XIE: Decomposition method for solving a nonlinear business cycle model

GHASSAN DIBEH: See ELIAS DEEBA

SALAH M. EL-SAYED: A two-sided iterative method for computing positive definite solutions of a nonlinear matrix equation

L. K. FORBES: See D. P. BULTE

J. M. GAFFNEY and C. E. M. PEARCE: Memory, market stability and the nonlinear cobweb theorem

A. B. GUMEL: See S. M. MOGHADAS

JONG-SHENQ GUO, CHU-PIN LO and JE-CHIANG TSAI: The structure of solutions for equations related to the motions of plane curves

W. D. HALFORD: See B. VAN BRUNT

P. J. HARRIS, H. AL-AWADI and W. K. SOH: An investigation into the effects of heat transfer on the motion of a spherical bubble

JACK HEIDEL: See JOHN MALONEY 
J. M. HILL: See G. M. COX

FALUN HUANG: See HONGXU LI

EMMA HUNT: A probabilistic algorithm for finding the rate matrix of a block- $G I / M / 1$ Markov chain

TADEUSZ JANKOWSKI: Minimal and maximal solutions to systems of differential equations with a singular matrix

B. JLMÉNEZ and V. NOVO: A notion of local proper efficiency in the Borwein sense in vector optimisation

M. KAMARUJJAMA: A unified presentation of generalised Voigt functions

T. K. KAR and K. S. CHAUDHURI: Harvesting in a two-prey one-predator fishery: a bioeconomic model

SUHEIL KHURI: See ELIAS DEEBA

DO SANG KIM: See PHAM HUU SACH

J. A. LANGA: See T. CARABALLO

GUE MYUNG LEE: See PHAM HUU SACH

HONGXU LI and FALUN HUANG: Minimal approximate Hessians for continuously Gâteaux differentiable functions

S. J. LI, X. Q. YANG, K. L. TEO and S. Y. WU: A solution method for combined semi-infinite and semi-definite programming

Z. F. LI, M. R. OSBORNE and T. PRVAN: Numerical algorithms for constrained maximum likelihood estimation

LISHAN LIU: See YAN SUN

YUJI LIU and BINGGEN ZHANG: Global attractivity of a class of delay differential equations with impulses

CHU-PIN LO: See JONG-SHENQ GUO

HONGWEI LOU: Existence of optimal controls for semilinear elliptic equations without Cesari-type conditions

S. K. LUCAS: Maximising output from oil reservoirs without water breakthrough $\quad 401$

JOHN MALONEY and JACK HEIDEL: An analysis of a fractal kinetics curve of Savageau

S. M. MOGHADAS and A. B. GUMEL: An epidemic model for the transmission dynamics of HIV and another pathogen

G. A. MOHR: Flow ratio design of primal and dual network models of distribution

G. A. MOHR and A. S. POWER: Natural cubic element formulation and infinite domain modelling for potential flow problems

P. MUTHU, B. V. RATHISH KUMAR and PEEYUSH CHANDRA: On the influence of wall properties in the peristaltic motion of micropolar fluid

M. I. NELSON and H. S. SIDHU: Bifurcation phenomena for an oxidation reaction in a continuously stirred tank reactor. II Diabatic operation.

NORHAYATI and G. C. WAKE: The solution and the stability of a nonlinear age-structured population model

V. NOVO: See B. JIMÉNEZ

DONAL O'REGAN: See RAVI P. AGARWAL

M. R. OSBORNE: See Z. F. LI

C. E. M. PEARCE: See SELMA BELEN 
C. E. M. PEARCE: See J. M. GAFFNEY

C. E. M. PEARCE and J. PEČARIĆ: On some switching inequalities of Brenner and Alzer

J. PEČARIĆ: See C. E. M. PEARCE

I. PENESIS, J. J. SHEPHERD and H. J. CONNELL: The pressure field in the gas-lubricated step slider bearing

D. PIDGEON: See B. VAN BRUNT

A. B. PLEASANTS, G. C. WAKE and C. C. DALY: Derivation of the probability density function for ultimate muscle $\mathrm{pH}$ in slaughtered animals

A. S. POWER: See G. A. MOHR

C. J. PRICE: See D. BYATT

T. PRVAN: See Z. F. LI

B. V. RATHISH KUMAR: See P. MUTHU

PHAM HUU SACH, GUE MYUNG LEE and DO SANG KIM: Efficiency and generalised convexity in vector optimisation problems

J. J. SHEPHERD: See I. PENESIS

H. S. SIDHU: See M. I. NELSON

W. K. SOH: See P. J. HARRIS

YAN SUN, LISHAN LIU and YEOL JE CHO: Positive solutions of singular nonlinear SturmLiouville boundary value problems

K. K. TAM: See M. AL-REFAI

XIANHUA TANG: See AIMIN ZHAO

K. L. TEO: See S. J. LI

PEDRO J. TORRES: Some remarks on a Neumann boundary value problem arising in fluid dynamics

JE-CHIANG TSAI: See JONG-SHENQ GUO

J. VALERO: See T. CARABALLO

B. VAN BRUNT, D. PIDGEON, M. VLIEG-HULSTMAN and W. D. HALFORD: Conservation laws for second-order parabolic partial differential equations

M. VLIEG-HULSTMAN: See B. VAN BRUNT

G. C. WAKE: See NORHAYATI

G. C. WAKE: See A. B. PLEASANTS

ZHICHENG WANG: See ZHENGQIU ZHANG

M. W. WONG and ZHAOHUI ZHANG: Traces of localisation operators with two admissible wavelets

S. Y. WU: See S. J. LI

SHISHEN XIE: See ELIAS DEEBA

JURANG YAN: See AIMIN ZHAO

H. YANG, G. YIN, K. YIN and Q. ZHANG: Control of singularly perturbed Markov chains: A numerical study

X. Q. YANG: See S. J. LI

G. YIN: See H. YANG

K. YIN: See H. YANG

BINGGEN ZHANG: See YUJI LIU

Q. ZHANG: See H. YANG 
YINGLONG ZHANG: See SONGPING ZHU

ZHAOHUI ZHANG: See M. W. WONG

ZHENGQIU ZHANG and ZHICHENG WANG: Periodic solutions of a two-species ratiodependent predator-prey system with time delay in a two-patch environment

AIMIN ZHAO, XIANHUA TANG and JURANG YAN: Oscillation of first-order delay differential equations

SONGPING ZHU and YINGLONG ZHANG: A flat ship theory on bow and stem flows 